\title{
Characterization of an area susceptible to floods and inundations in a medium size city in Southern Brazil
}

\begin{abstract}
The change in precipitation patterns that has occurred over the past decades establishes the discussion about the risks arising from rainfall in urban areas. These risks include floods, inundations and overflow, which are influenced by different conditions. The purpose of this work is to characterize a risk area, susceptible to inundations and floods, in the city of Passo Fundo, in the south of Brazil. In order to propose solutions aimed at mitigating risks for the area, a GIS (Geographic Information System) characterization was applied to prepare thematic maps to identify conditions of infrastructure networks, as well as other constraints of the built environment. The analysis showed that the area, predominantly residential, is currently susceptible to environmental risks, given the proximity to streams, the topography with slopes and impermeable surfaces, despite the existence of rain network infrastructure. Furthermore, the mitigation strategies were proposed, based on the concept of green infrastructure such as the implementation of draining surfaces, rain gardens and a linear park. The data collected in this study will provide subsidies to elaborate the risk maps of the area, deepening the analysis in future studies, assisting the decision making of the public power to prevent and mitigate risks such as floods, according to the identified vulnerability, as well as contribute to Goal 11 - Sustainable cities and communities on the United Nations Agenda 2030.
\end{abstract}

Keywords: flood, resilient cities, sustainable cities, risk areas, GIS, sponge cities
Volume 5 Issue 5 - 202I

\author{
Sidnei Matana Júnior,Yohan Casiraghi, \\ Gabriela Weimer Berres, Marcos Antonio \\ Leite Frandoloso, Francisco Dalla Rosa \\ Civil and Environmental Program, Faculty of Engineering and \\ Architecture, University of Passo Fundo, Brazil
}

\begin{abstract}
Correspondence: Marcos Antonio Leite Frandoloso, Civil and Environmental Program, Faculty of Engineering and Architecture, University of Passo Fundo, Campus I - Bairro São Jose, Passo Fundo - RS, Brazil, +55 54 99994-7887,

Emailfrandoloso@upf.br
\end{abstract}

Received:September 0I, 202I | Published: September 14, 2021
Abbreviations: ANA, brazil national water agency; BID, banco interamericano de desenvolvimento; IPCC, intergovernmental panel on climate change; SDG, sustainable development goal; UN, united nations; ZPRH, water resources protection zone; ZPMN, native forest protection zone; ZEIS, social interest special zone; ZOC1, controlled occupation zone 1; CAPES, coordination for the improvement of higher education personnel; FUPF, university of passo fundo fundation

\section{Introduction}

The impacts of natural disasters arise from different threats factors such as landslides, fires, hurricanes, droughts, among others, the level of exposure, referring to the time and space in which people, buildings and natural assets and vulnerability are inserted, related to the intensity to which a person or assets can be affected by threats. In this context, climate change is considered as a condition of alteration or intensification of these events. ${ }^{1}$ By analyzing precipitation data over last decades, it is possible to see a change in the behavior of natural events, such as the terrestrial temperature increment, and the change in rainfall across the planet as well. According to the Intergovernmental Panel on Climate Change - IPCC, ${ }^{2}$ it is likely that the frequency of intense rainfall and extratropical cyclone areas will increase with the continued warming of the planet, induced by the increase in greenhouse gas concentrations.

The climate scenario for the southern region of Brazil indicates an increase in precipitation between $5 \%$ and $10 \%$ by 2040 and $15 \%$ to $20 \%$ between 2041 and 2070. This forecast sets a scenario discussion about the risks that can be caused by this increase in precipitation, especially in urban areas. ${ }^{3}$ The occurrence of these events mainly affects communities more vulnerable, as they are most often unable to deal with the risks, as well as having difficulties to return to the normal state. ${ }^{4}$

The socio-environmental character of these risks and the multidisciplinary studies reinforce the importance of studies on the consequences of rains in the urban environments. ${ }^{5}$ In addition, Goal 11 of the 17 Goals for Sustainable Development of the United Nations ${ }^{6}$ deals with sustainable cities and communities, having in goal 11.b to increase by 2020 the number of cities that adopt strategies and plans that include disaster resilience and climate change mitigation guidelines, as well as implement holistic risk management associated with disasters, as per the Framework Sendai 2015-2030, which addresses risk reduction at all levels.

The water balance in cities is affected by anthropic actions, such as buildings, pavements, and solid waste, modifying the speed of surface runoff, and consequently, the volumes that infiltrate into the soil to groundwater or that will undergo evapotranspiration. In the urban environment, the risks related to rainfall and influenced by anthropic action are floods, inundations, and overflows. As they result from the rains, the three phenomena can be considered natural, however, it is necessary to consider how anthropic actions influence the magnitude or frequency on these phenomena, associated with other variables as soil compaction and waterproofing, such the alteration of natural courses, make them hybrid risks. ${ }^{5}$

Urban flooding occurs when the waters of rivers, streams, storm sewers come out of their beds and occupy areas where the population uses for housing, transport, recreation, commerce, industry, due to the lack of transport capacity of a or more systems. ${ }^{7}$ The flood is associated with the elevation of the level of water courses, without overflow and on a temporary basis, while the inundations consider the overflow 
that reaches floodplain areas, with urban inundations resulting from actions anthropogenic and natural, intensified by the urbanization process. Overflows are related to the increase in the surface runoff of rainwater, due to the urbanization and soil waterproofing, altering the natural course of water. ${ }^{5}$

According to the Organization of United Nations - UN, the occurrence of these problems can result in direct damage and losses of physical and environmental assets, including belongings and human shelter, systems and ecological production in economic sectors, as well as issues related to health and loss of human life. For this reason, floods are considered one of the more expensive natural disasters due to the large damage caused. In a study of natural disasters in America Latin and the Caribbean, between 2000 and 2019, Brazil is among the top 15 countries in the world with the largest population exposed to the risk of flooding rivers, with 7,406,000 in this area affected by floods ${ }^{8}$. For climate-resilient urban occupation it is essential that an efficient urban planning be carried out, because the aspects of form interfere directly in the movement of people and products through the city, as well as in the patterns of consumption of natural resources. Therefore, a balanced relationship can be built between man and nature, with cities adapted to reduce their respective vulnerabilities. ${ }^{9}$

There are structural and non-structural measures that can be taken into account when analyzing possible flood and inundation risk management strategies. Both are characterized as structural measures, the heavy engineering work and structures, which need greater investment, such as flood defenses and water channels, drainage, as well as complementary or alternative measures, for instance wetlands and natural tampons. Non-structural measures are organized into four basic objectives that generally do not require heavy investments like structural ones but need a greater knowledge of the area. The first objective is the planning and management of emergency including alert and evacuation; the second objective is greater preparation of the population through awareness campaigns; the third objective is to be able to prevent flooding through land use planning; and the fourth objective is to accelerate the post-flood recovery and use to increase resilience through project improvement of construction and the construction itself. ${ }^{10}$

As the practical guide for sustainable buildings, public spaces and flowerbeds in Brazil from the Inter-American Development Bank, ${ }^{1}$ the concept of sponge cities or sustainable drainage systems, uses green infrastructure for water are absorbed in the proper places or close to the precipitation, reproducing the cycle natural waters, instead of producing the flow of these. This concept allows to reduce impacts such as flooding, overflows, inundations and other events related to rain. Among the strategies of this concept is the combination of gray infrastructures, waterproof and buildings, with green infrastructure, consisting of vegetation, green areas, permeable floors, spaces for urban agriculture, among other strategies, arranged in different urban scales. Figure 1 shows the operating scheme of a sponge city:

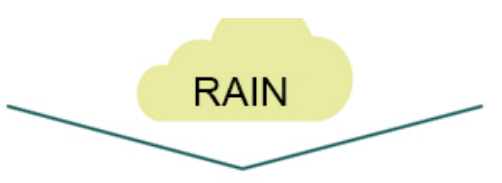

SPONGE CITY TECHNOLOGIES

OBJECTIVES

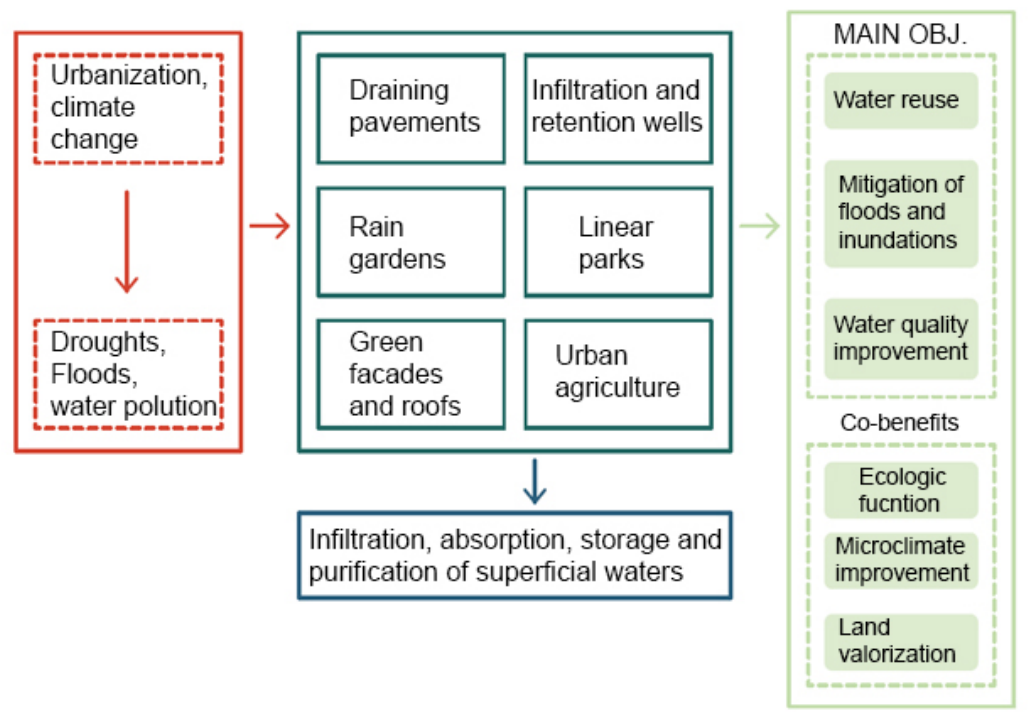

Figure I Concept of sponge cities. Source: BID (2020).

The linear parks elaborate a strategy for the recovery of water bodies, allow to restore ecosystems, recover degraded areas, connect green areas, assist in flood control, in addition to the possibility of use for leisure and environmental education. ${ }^{1}$ Urban green corridors also contribute to building a resilient city, by mitigating the impacts of urban sprawl, by creating microclimates, improved drainage and attributing quality to urban space. ${ }^{11}$
Rain gardens can be used as a strategy for increase the permeability of urban spaces, which contribute to reducing erosion and use of suitable plant species, preferably native species, allows to retain part of the water and pollutants that would be infiltrated into the soil or carried away in the case of impermeable surfaces. ${ }^{12}$ In addition, this infrastructure allows the increase of air humidity, mitigation of urban heat islands, landscape quality of open spaces, reduced flow velocity of rainwater and irrigation of surrounding vegetation. ${ }^{1}$ 
For these reasons, there are research and project efforts aimed at increasing the resilience of communities exposed to risks or residing in susceptible areas. ${ }^{13}$ The urban resilience can be conceptualized as the capacity that individuals, communities, systems, among others in a city must survive, regardless of what types of chronic stresses and acute shocks they experience, if adapting and growing. Many works focused on defining the concepts of urban resilience in detriment of analyzing how to implement the strategies and policies that promote this process, in addition to questioning how public policies affect urban resilience. ${ }^{14}$

Planning instruments, such as Municipal Sanitation Plans, can contribute to the sense of mitigating risks, through the identification of critical areas, susceptible to flooding and inundations, through the implementation of monitoring systems and control measures. ${ }^{15}$ Multi-criteria analysis using GIS (Geographic Information System) software, considering elements such as drainage infrastructure, presence and proximity to water flows, altitude, slope and land use allow for an important approach to management and mitigation of risks in urban areas. ${ }^{16}$

In this context, the objective of research is to characterize an area at risk, susceptible to flooding and inundations in Passo Fundo, located in the south of Brazil, using GIS software and from the surveys propose mitigation actions based on the concept of green infrastructure and sponge cities.

\section{Material and methods}

The study area is located in Passo Fundo, a city in Southern

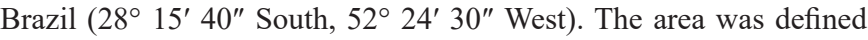
from the Basic Sanitation Plan of Passo Fundo, ${ }^{17}$ which indicates points susceptible to flooding and overflows in the urban area of the municipality. For the selected area, three locations of risk, which were assessed together, in accordance with the analysis procedures described below. Figure 2 shows the location of the study area:

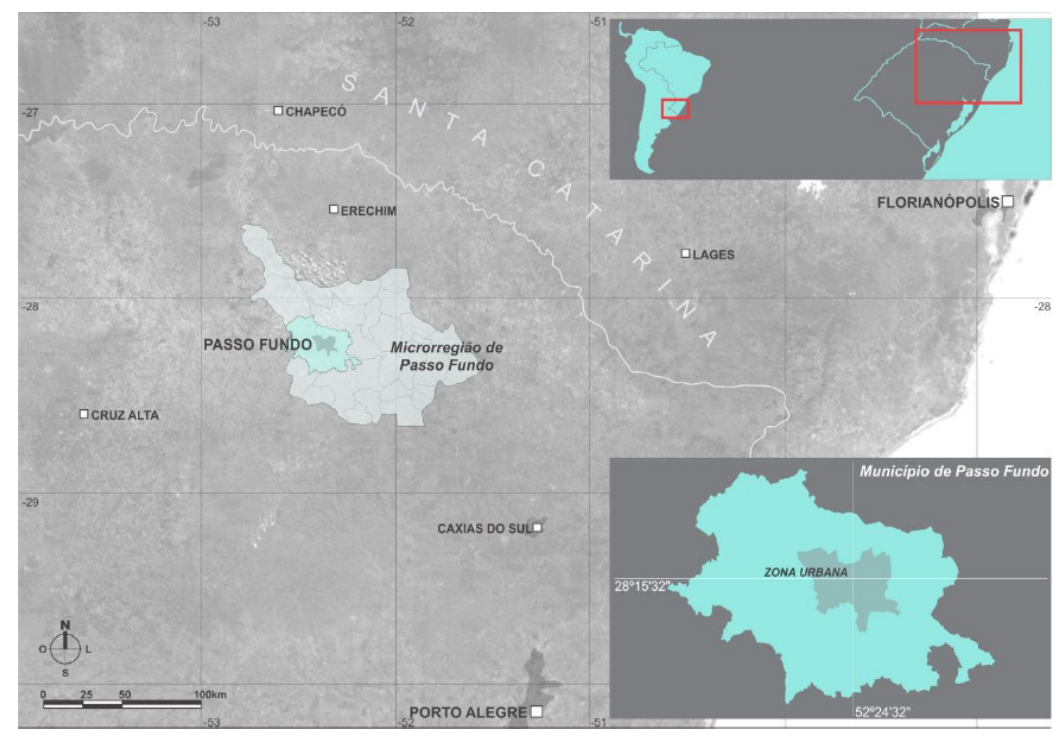

Figure 2 Location of Passo Fundo. ${ }^{17}$

\section{Study area characterization}

Passo Fundo is a medium-sized city, with an estimated population higher than 203 thousand inhabitants. ${ }^{18}$ The municipality is a regional hub, due to the provision of diversified health, education and trade services, being the $12^{\text {th }}$ most populous municipality in the state. The climate is from fundamental wet type (f), subtropical variety (Cfa), as per Köppen classification. ${ }^{19}$

The rain precipitation distributed throughout the year, wherein the months of March, July, August and November are characterized as less rainy and the month of October the rainier. ${ }^{20}$ However, in the last five years the precipitations of the rainy season have been consistently exceeding the maximum rainfall values in three years, while the less rainy periods in some years have values far below the average, in 2015 the accumulated rainfall exceeds the normal in $24 \%$ and $32 \% .{ }^{21}$ Figure 3 shows the comparison of rainfall distribution of normal climatological and the year 2019:

After identifying the normal data in relation to precipitation, it was observed that the year 2019 presented values adverse to those identified in the period from 1961 to 1990. For instance, September records a total rainfall of $206.8 \mathrm{~mm}$ in the historical series and in the year 2019 the precipitation in the same month did not reach $100 \mathrm{~mm}$. October, based on the historical series, used to be present $167.1 \mathrm{~mm}$ of precipitation, recorded values above $300 \mathrm{~mm}$ in the year of 2019 , demonstrating the change in rainfall patterns in the municipality, which evidence are also related to seasonal events that influence precipitation in the South region of Brazil.

Passo Fundo had its first sanitation plan between 1919 and 1923, that accounted the topography, sewage, and water supply systems, in addition to forecasting areas greens in places of difficult sanitary sewer execution..$^{22}$ After the first masterplan in 1953 and its revisions in 1984 and 2006, the new sanitation plan ${ }^{17}$ comes into effect in 2014, characterizing the city through diagnoses of the drinking water collection and supply services, urban drainage and water management rainwater, collection and disposal of sanitary sewage, solid waste and urban cleaning services as well as forecasts and methods of evaluating the plan's goals.

Prior to the sanitation plan, the revision of the master plan in 2006 also defined permeability indices for each zone within the urban fabric, presenting permeability rates ranging from $10 \%$ to $90 \%$ of 
the property surfaces, with protection zones also being established water resources protection zones (ZPRH) and native forest protection zones (ZPMN), where low land cover rates for buildings are defined along with high permeability rates. In addition to these, there are also zones of controlled occupation, close to water resources, with construction indices lower than the densification zones. These indices were adjusted by the sanitation plan in 2014.

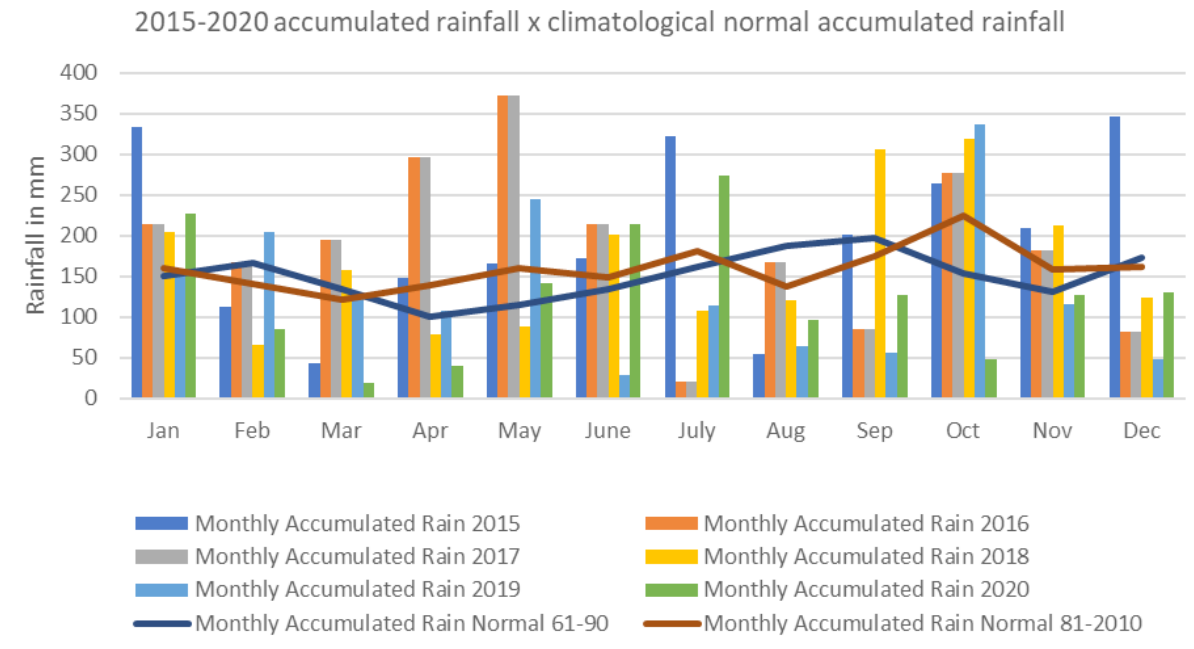

Figure 3 Comparison between accumulated monthly rainfall in 2015-2020 and climatological normals. ${ }^{21}$

According to the Municipal Basic Sanitation Plan, ${ }^{17}$ it was established different permeability rates for each area of the city, the percentage being corresponding to the minimum portion of the lot corresponding to the permeable area of the soil, being the area the area with the lowest permeability rate in the city center. Figure 4 demonstrates the location of each of the areas with their respective permeability rates.

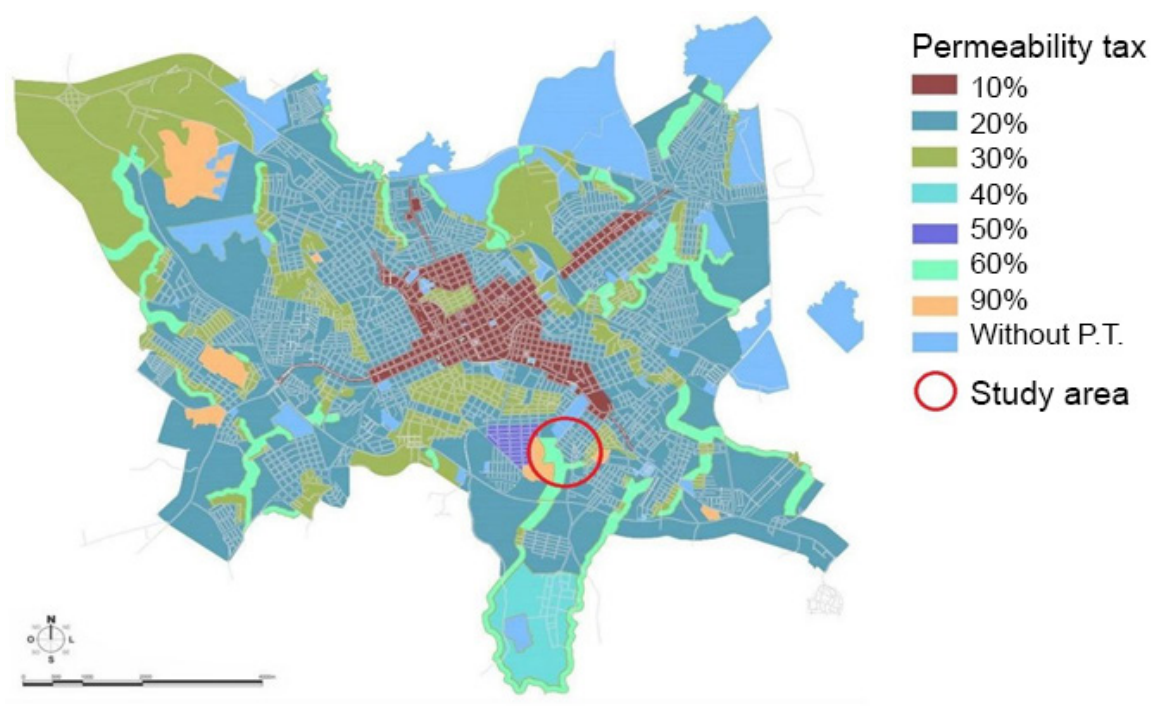

Figure 4 Permeability rates in the urban area of Passo Fundo. ${ }^{17}$ adapted by the authors.

The study area was selected through the map of points susceptible to flooding and inundations identified in the city sanitation plan, the stretch being defined with 3 close points. Figure 5 below shows the location of the study area in the city:

The delimited stretch is located in São Cristóvão district, comprising an area of 14.2 hectares, consisting of two Special Zones of Social Interest (ZEIS), part of the Zone of Controlled Occupation 1 (ZOC1) and also Water Resources Protection Zone (ZPRH), between Portão stream, to the Southwest, Francisco Maciel Street to the Southeast, Rosário street to the Northwest and Brigada Militar street to the Northwest. Figure 6 shows the zoning and views of the study area.

The predominant land use is residential, in general one-story homes or up to 2 pavements, and in the stretch between Olívia Fior Street and the Portão stream, 67 single-family social interest homes, in ZEIS 1, where the Wolmar Salton Municipal School. There is also an area of irregular occupation, located in the zone ZEIS $3 .{ }^{24}$ The Portão stream, within a protection zone for the water resources - ZPRH, according to the zoning map of the city master plan, ${ }^{20}$ delimits the study area as a reference for evaluating areas susceptible to floods and inundations. 


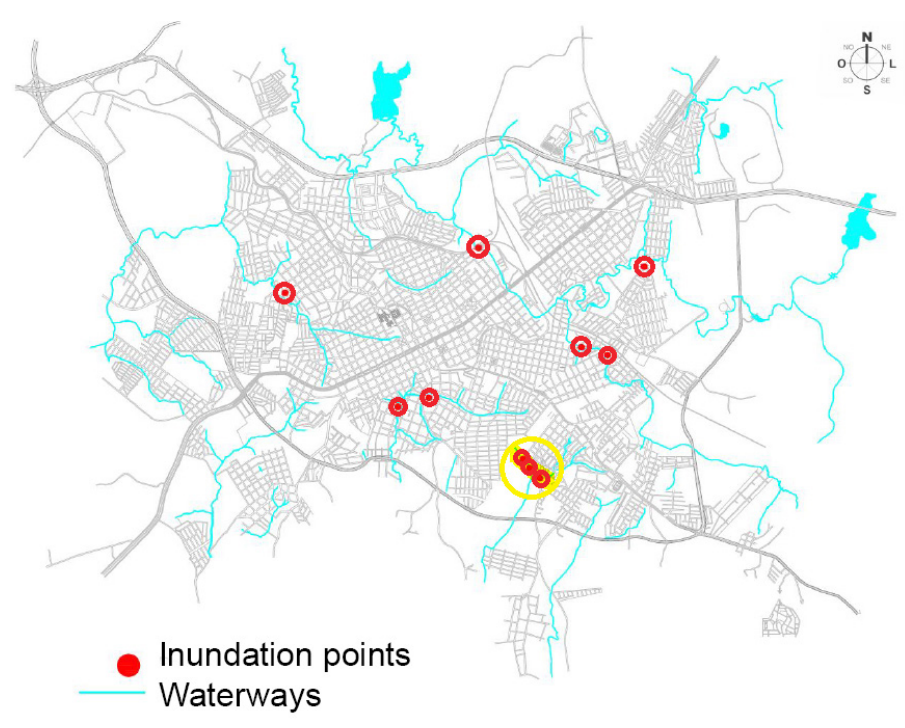

Figure 5 Location of the study area and points and inundation and flooding. ${ }^{17}$ adapted by the authors.
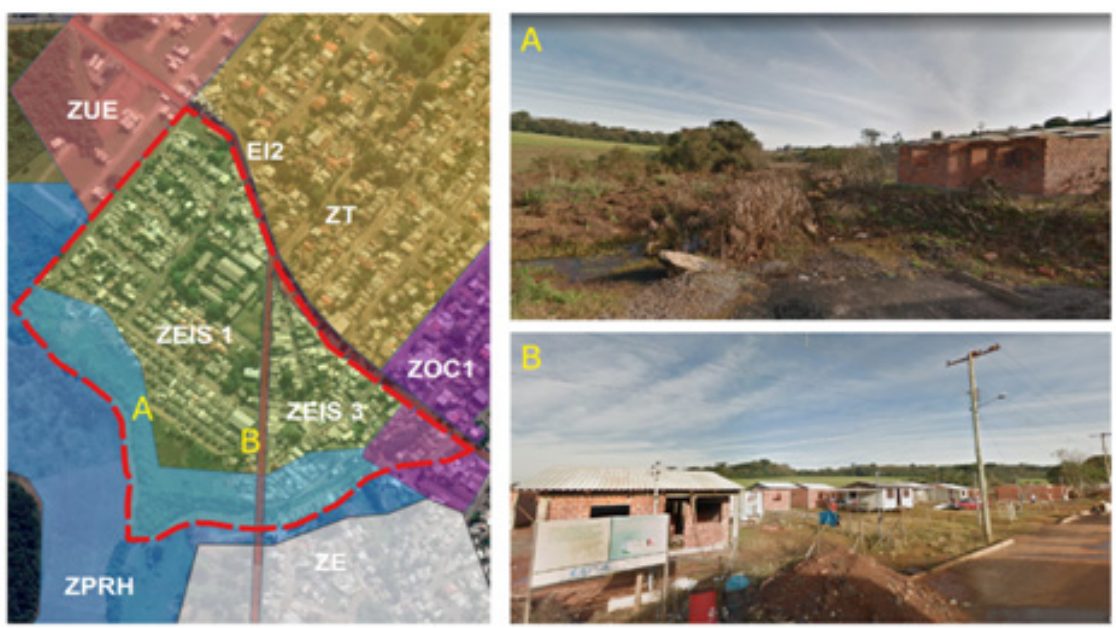

Figure 6 Zoning and views of the study area. ${ }^{23}$ adapted by the authors.

\section{Analysis procedure}

Surveys of the area were carried out using the georeferencing QGIS $^{23}$ software, version 3.12.3 and Google Earth map base. Data related to rain collection infrastructure such as networks, pluvial manhole, as well as topography were identified through thematic maps. Elevation maps were generated from the Digital Terrain Model (DTM) method, spatial resolution of 30.0 meters, using data EMBRAPA relief, inserted in the QGIS software. For the analysis of the elevations, we used the Autocad Civil 3D software, version 2019, ${ }^{25}$ with the insertion of data from contour lines and color mapping was obtained at each elevation interval through the Elevation Analysis tool, which can be seen in Figure 4.

After the presentation of the results obtained, the thematic maps are presented for analysis of susceptibility to risks and also to suggest measures to reduce the risks in the study area, evaluating aspects related to physical characteristics, infrastructure availability, whether the presence or absence of permeable areas, among other aspects.

The multicriteria analysis, according to Alves et al. ${ }^{16}$ evaluates the area in terms of the following criteria: slope, obtained through the elevation model to identify the lowest elevations and flat areas, susceptible to flooding; the altitude, the lower, the more susceptible to floods; drainage elements close to the roads; the presence and proximity of bodies water and land use, considering the impermeable areas.

In this way, the combination of different layers of the territory, whether environmental variables or constructed elements, will allow the identification of conditions for the generation of risks associated with flooding, as well as the identification of places to implement mitigation strategies.

\section{Results}

From the surveys, thematic maps were drawn up, helping in the identification of risk areas susceptible to flooding and inundation. The area has level between 626 and 690 meters of altitude, the area of the Portão stream being the lowest and where rainwater is directed, as shown in Figure 7 below:

Elements of the urban drainage network were identified, such as pluvial manhole and the existing underground network, in addition to the permanent preservation area, considering 30 meters by the Brazilian current law in relation to the axis of the stream, as shown in Figure 8 below: 


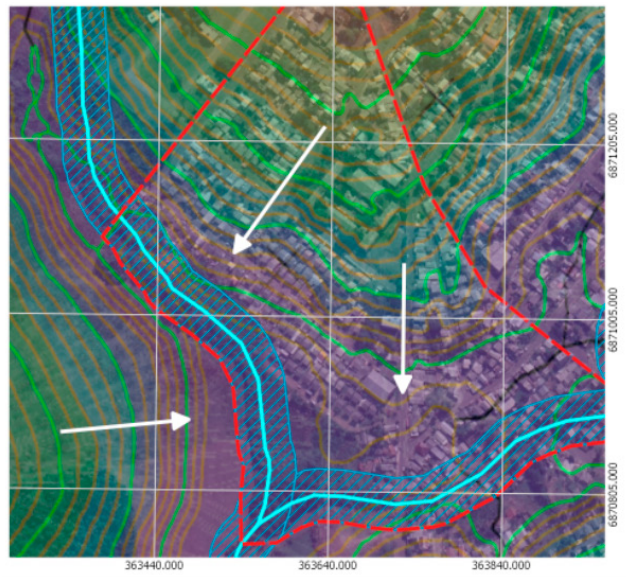

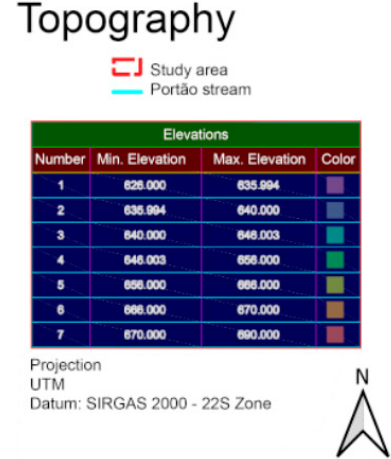

Scale

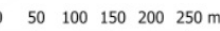

Figure 7 Topographic survey of the study area ${ }^{23,25}$ adapted by the authors.

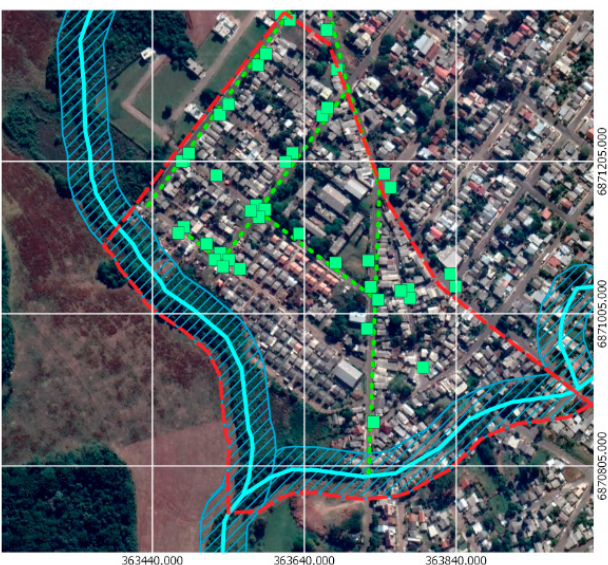

\section{Conditions and infrastructure}

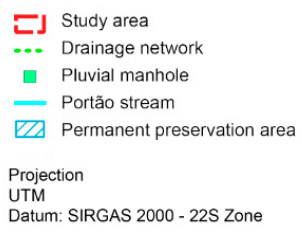

Figure 8 Rainfall infrastructure of the study area, ${ }^{23}$ adapted by the authors.

The area has drainage infrastructure, however, at the lower elevations, from the Olívia Fior street, few pluvial manholes have been identified, there is still an access easement, close to the stream, where no drainage infrastructure was identified. Concerning about the streets in the area are asphalted, a factor that contributes to the speed of rainwater runoff and reduce the water infiltration. The absence of selective collection containers, as in other areas of the city, or even other solid waste collection systems, is a factor to be considered, by the possibility of closing the sewers or even contamination of the Portão stream. From the surveys, considering the characteristics of the topography, availability of a drainage network and proximity to water courses, a map identifying the areas susceptible to flooding and inundation, as shown in Figure 9 below:

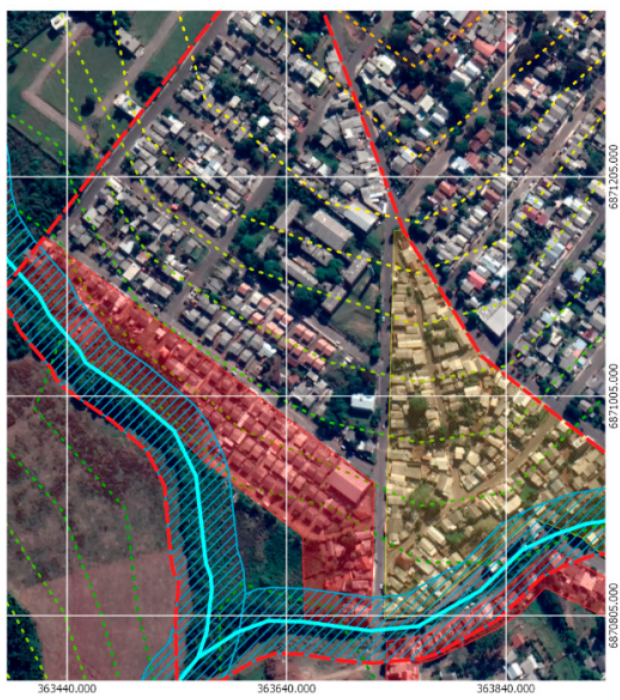

Susceptible areas:

Floods and

\section{overflows}
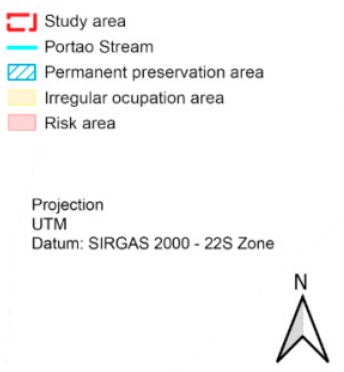

Scale

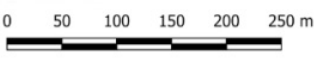

Figure 9 Characterization of the risk area, ${ }^{23}$ adapted by the authors.

Citation: Matana Júnior S, Casiraghi Y, Berres GW, et al. Characterization of an area susceptible to floods and inundations in a medium size city in Southern Brazil. Int J Hydro. 202 I;5(5):222-229. DOI: 10.15406/ijh.2021.05.00284 


\section{Discussion}

As the practical guide for sustainable buildings, public spaces, and flowerbeds in Brazil ${ }^{1}$ the use of green infrastructure, such as permeable pavements, vegetation, urban parks, rain gardens, green roofs and other strategies are integrated to the gray infrastructure, considering buildings and roads. The green infrastructure, in addition to mitigating impacts related to rainfall, also produces positive impacts on air quality and heat island reduction, as well as contributing to urban resilience. Figure 10 shows the proposals to mitigate risks:

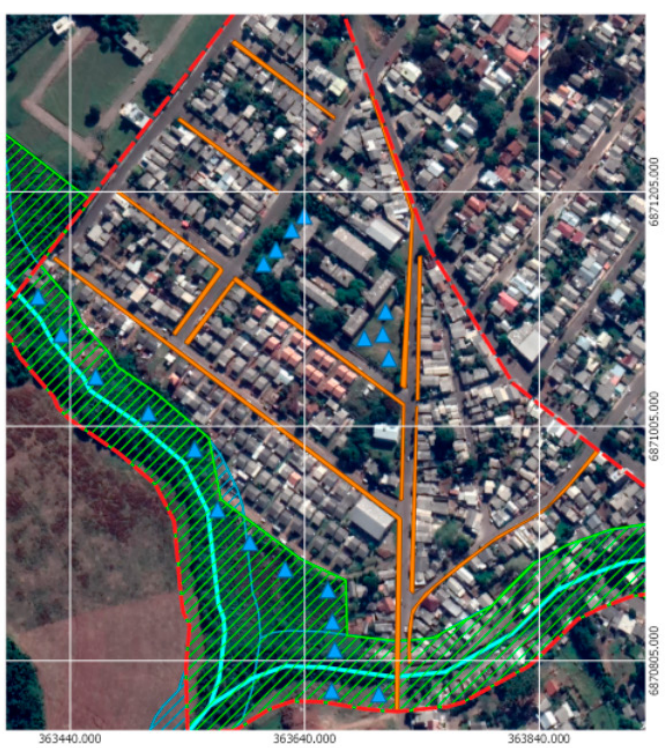

\section{Suceptible areas: \\ Mitigation proposals}

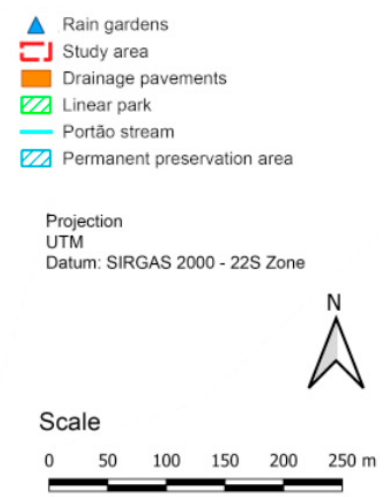

Figure 10 Proposed mitigation strategies, ${ }^{23}$ adapted by the authors.

In the study area, the first proposal to be made is the replacement or regularization the pavement of the sidewalks, using drainage floors and vegetation, as well as the execution of curb and sidewalk in lots that do not have them, mainly in places that are below street level. The implementation of rain gardens, in addition to the benefits related to rainwater infiltration, can also be used as an element of environmental education in schools, being implemented at the Wolmar Salton School, located in the center of the study area.

Another proposal for risk mitigation would be the implementation of a linear park, a public use space with leisure spaces such as bicycle paths, outdoor gym, spaces for coexistence, rain gardens, space for environmental education, among other activities, strategy already used to revitalize other public spaces in the municipality. The residents of the residences in the permanent preservation area, along Francisco Maciel Street should be relocated to a nearby area, as well as discussing the regularization of the properties of the irregular occupation in ZEIS 3. These proposals should be integrated in studies of Urban Reform (REURB) being implemented by the municipality of Passo Fundo.

The climate change is affecting the rainfall all over the world, by different manners. In Nigeria, even identifying an increase in rainfall, identified that water resources were not replenished naturally, highlighting the need for measures to verify water, flooding and underutilization of wetlands. ${ }^{26}$ In Senegal and The Gambia, the rainfall deficit was estimated at $10 \%$, in West Africa it reaches $20 \%$ to $25 \%$, affected by droughts and land use, evidencing the need to consider climatic variables in the management of water resources. ${ }^{27}$ In Bahia, a state in northeastern Brazil, a downward trend in rainfall in the historical series was also identified, indicating a change in the water pattern. $^{28}$
The study is replicable to other risk areas in Brazil and Latin America, where similar situations occur due to the climate variation. The proximity of water courses, impermeable surfaces and insufficient drainage infrastructure, aggravated by the irregular occupation of urban space, expose the populations to risks associated with rain, with a tendency to worsen due to climate change.

Other strategies, such as green roofs, can contribute to the retention of rainwater, not contaminating the water that would be drained and even allowing its reuse for other purposes..$^{29}$ Regarding the water cycle in the urban environment, the concept of sponge cities will modify the existing infrastructure, necessitating the study of improvements or replacement of existing networks, as well as bringing more demands on maintenance and operation. ${ }^{30}$

In other cities, the risks are also aggravated by erosion and susceptibility to landslides. In this sense, the study contributes to demonstrate the application of multi-criteria analysis in identifying risk areas, as well as introduces concepts of sponge cities that can be applied and substantially contribute to the reduction of risks associated with floods and floods.

\section{Conclusion}

Events related to climate change can interfere with the intensity and frequency of rains. In Passo Fundo, rainfall in recent years indicate changes in the rainfall regime in relation to historical averages, highlighting the importance of carrying out studies and strategies aimed at mitigating risks such as inundations and floods.

The identification of areas susceptible to these phenomena allows the elaboration of strategies focused on urban resilience, contributing to the safety of populations in vulnerable areas. In urban environments, 
waterproofed surfaces, buildings and waste derivatives of anthropic action may contribute to the intensification of hybrid risks related to rainwater.

The study identified factors that contribute to the increased risks, such as the established physical and natural environment conditions, as well as the possibility of implementing mitigation proposals based on the concept of sponge cities and resilient cities, aiming to contribute to Goal 11 of the 2030 agenda, by selecting strategies that reduce the risks associated with flooding and flooding in urban areas.

The use of GIS software and multi-criteria analysis can be used to detail other areas susceptible to risks, as well as identifying new areas of risk arising from the expansion of the urban area of Passo Fundo. In addition, future infrastructure modifications existing at the site can be identified from new surveys and comparison with the data covered in this research.

Preliminary data from the study can be used as a basis for preparing the risk map of the area, through the deepening of the analyzes initiated in this study, in future works, it should be noted that the same procedure can be replicated for others critical points indicated in the Basic Sanitation Plan, providing subsidies for the process decisionmaking by public managers, in order to act towards prevention and mitigation of risks arising from floods and inundation, according to susceptibility identified.

\section{Acknowledgments}

The authors would like to thank CAPES and FUPF for the financial support.

\section{Conflicts of interest}

The authors declare have no conflict of interest.

\section{References}

1. BANCO INTERAMERICANO DE DESENVOLVIMENTO - BID. Vamos construir verde? Guia prático para edificações, espaços públicos e canteiros sustentáveis no Brasil. 2020.

2. INTERGOVERNMENTAL PANEL ON CLIMATE CHANGE - IPCC. Changes in Climate Extremes and their Impacts on the Natural Physical Environment. 2018.

3. Goulart AA, Fogaça TK. Introdução à climatologia: conceitos, pesquisas e ensino. Curitiba: Intersaberes; 2018.

4. AGÊNCIA NACIONAL DE ÁGUAS - ANA. Mudanças Climáticas e Recursos Hídricos: Avaliações e Diretrizes para Adaptação. 2016.

5. Castelhano FJ. O clima e as cidades. Curitiba: Intersaberes, 2020.

6. UNITED NATIONS - UN. Objetivo 11. Tornar as cidades e os assentamentos humanos inclusivos, seguros, resilientes e sustentáveis. 2020.

7. Tucci, C. E. M. Gerenciamento integrado das inundações urbanas no Brasil. Revista de Gestão de Água da América Latina. 2004; 1 (1): 59-73.

8. UNITED NATIONS - UN. Natural disasters in Latin America and the Caribbean. 2020.

9. Apollaro C, Alvim AB. Planejamento urbano para a adaptação de cidades frente à mudança climática: uma análise sobre o Plano Diretor Estratégico do Município de São Paulo. Thésis. 2017;2(4):118-137.
10. Jha AK, Bloch R, Lamond J. Cidades e inundações. Um guia para a gestão integrada do risco de inundação urbana para o século XXI. 2012.

11. Cortez R, Moura NC, Machado C. Análise do desempenho das melhores práticas de manejo para constituição de corredores verdes em FortalezaCE. Paisagem E Ambiente. 2019;30(43).

12. Katsifarakis KL, Vafeiadis M, Theodossiou N. Sustainable Drainage and Urban Landscape Uprgrading Using rain gardens. Site Selection in Thessaloniki, Greece. Agriculture and Agricultural Science Procedia. 2015;4:338-347.

13. Prates TOB. Vulnerabilidade socioambiental nas áreas suscetiveis as inundações no baixo curso da bacia hidrográfica do Rio Muriaé (RJ). Dissertation (Master dergree) - Instituto de Geociências, Universidade Estadual de Campinas, Campinas, 2019.

14. Spaans M, Waterhout B. Building up resilience in cities worldwideRotterdam as participant in the 100 Resilient Cities Programme. Cities. 2017;61:109-116.

15. Shamsuddin, S. Resilience resistance: The challenges and implications of urban resilience implementation. Cities; 2020;103:1-8.

16. Alves PBR, Melo Filho H, Tsuyuguchi BB, et al. Mapping of flood susceptibility in Campina Grande county - PB: a spatial multicriteria approach. Bulletin of Geodetic Sciences. 2018; 24(1): 28-43.

17. Passo Fundo. Plano de saneamento básico Município de Passo Fundo. 2014

18. Instituto Brasileiro de Geografia e Estatística - IBGE. Passo Fundo. 2020.

19. EMPRAPA. Clima de Passo Fundo - Normais climatológicas. 2001.

20. Passo Fundo. Diagnóstico participativo Volume I. 2019a

21. Instituto Nacional de Metereologia - INMET. Chuva acumulada mensal x chuva (normal climatológica 61-90). 2020.

22. Gosch LRM. Passo Fundo: De Saturnino de Brito ao Mercosul. 2002. Dissertation (Master degree) - Programa de Pós-Graduação em Urbanismo, Universidade Federal do Rio de Janeiro, Rio de Janeiro, 2002.

23. Team, QGIS Developement. QGIS geographic information system. Open source geospatial foundation project, 2020.

24. Passo Fundo. Mapa de zoneamento urbano do Municipio de Passo Fundo. 2019b.

25. Autodesk, INC. Autodesk Civil 3D 2019. Versão 13.0.6, Software Owner, Educational License, 2019.

26. Ogunbode TO, Ifabiyi PI. Rainfall trends and its implications on water resources management: a case study of Ogbomoso city in Nigeria. Int $J$ Hydro. 2019;3(3):210-215.

27. Faty A, Kouame F, Fall AN, et al. Land use dynamics in the context of variations in hydrological regimes in the upper Senegal River basin. Int $J$ Hydro. 2019;3(3):185-192.

28. Simões YDS, Araújo HAD, Cohim E. Trend analysis of rain indicators for the state of Bahia, Brazil. Int J Hydro. 2020;4(2):67-74.

29. Costa $\mathrm{CH}$, Gonçalves SFG, Silva CL, et al. Water balance study on green roof in Brazil. Int J Hydro. 2020;4(4):141-144.

30. Köster S. How the Sponge City becomes a supplementary water supply infrastructure. Water-Energy Nexus. 2021;4:35-40. 